Article

\title{
Identification of DNA Markers of Anthocyanin Biosynthesis Disorders Based on the Polymorphism of Anthocyanin 1 Tomato Ortholog Genes in Pepper and Eggplant
}

\author{
Olga Babak *, Tatiana Nikitinskaya, Nataliya Nekrashevich, Konstantsia \\ Yatsevich, Alexander Kilchevsky \\ Laboratory of Ecological Genetics and Biotechnology, the Institute of Genetics \\ and Cytology, NAS of Belarus, Minsk 220072, Belarus \\ * Correspondence: Olga Babak, Email: babak_olga@mail.ru
}

\begin{abstract}
The aim of this research was the identification of DNA markers to Antocyanin 1 (Ant1) tomato orthologs in 30 Capsicum annuum, 30 Solanum melongena and 1 Solanum aethiopicum accessions with different anthocyanin accumulation. A search for orthologs to the Ant1 allele in the GenBank database revealed the following closest nucleotide sequences of Myb113-like TF: in C. annuum, mRNA XM_016689227, mRNA NM_001324618; in S. melongena, mRNA KT259043. In Capsicum spp. samples, 4 SNP and a single base deletion in exon 3 of the Myb113-like 1 allele and 2 SNP in exon 4 of the Myb113-like2 allele were detected in forms with the impaired anthocyanin synthesis, based on their phenotype.
\end{abstract}

In S. melongena samples, a 6 bp deletion at the end of exon 1 of the $M y b-1$ gene was detected in accessions with a green fruit coloration. A $26 \mathrm{bp}$ deletion between intron 1 and exon 2, 11 SNP in exon regions and a $52 \mathrm{bp}$ insertion at the beginning of intron 2 were detected in forms with a white fruit coloration. A 9-nucleotide insertion and 11 SNP in exon 3 of the $M y b$ - 1 gene were detected in the S. aethiopicum accession with no anthocyanin accumulation in fruits.

\section{G Open Access}

Received: 29 November 2019

Accepted: 31 May 2020

Published: 05 June 2020

Copyright (C) 2020 by the author(s). Licensee Hapres, London, United Kingdom. This is an open access article distributed under the terms and conditions of Creative Commons Attribution 4.0 International License.
Optimal SCAR and CAPS markers were developed to identify a number of genetic polymorphisms of Myb-like TF genes that might cause the impaired anthocyanin synthesis in pepper and eggplant. CAPS Myb 113AccI and dCAPS Myb 113-AciI markers allow to identify C.annuum accessions without an anthocyanin coloration of fruits. SCAR MybMel and CAPS Mybmel-PstI markers allow to identify S. melongena accessions with white and green fruit colorations.

Samples with different allelic polymorphism combinations were selected as models for the further study of the genetic regulation of anthocyanin accumulation in various parts of plants and for improved plant breeding. 
KEYWORDS: Solanum lycopersicum; Capsicum annuum; Solanum melongena; regulation of anthocyanin synthesis; DNA markers

\section{INTRODUCTION}

Anthocyanins belong to a group of flavonoids. These biologically active compounds are derived from benzo- $\gamma$-pyrone and are based on a phenylpropene skeleton consisting of C6-C3-C6-carbonic units [1].

Being one of the forms of secondary plant metabolites, anthocyanins do not only provide a particular coloration for various parts of plants, but also determine resistance both to abiotic and biotic stress factors. The ever-growing attention to this area of research stems from the antioxidant and antimicrobial properties of certain enzymes consumed by humans with plant foods [1,2]. The Solanaceae is a proper model allowing to study the genetic regulation mechanisms of anthocyanin accumulation due to the wide inter- and intra-species polymorphism of their accumulation in various parts of plants.

To date, the structure and functions of these compounds have been well-studied, and the regulation mechanisms determining their accumulation and depending on environmental conditions and genetic structure have been shown. A review article by Y. Liu et al. [2] has compiled investigation results on the biosynthesis and degradation mechanisms of these compounds based on more than 130 scientific articles' analysis, a significant part of which gives consideration to the genetic regulation of such mechanisms.

The allelic polymorphism study of these regulatory genes is important due to the fact that the structural genes of an anthocyanin biosynthetic pathway function under the control of a regulatory complex called MYBbHLH-WD40 (MBW) [2], and R2R3Myb-activators are key elements of this complex [2].

Genetic databases provide data on the gene sequences of a number of Myb factors that determine the accumulation of various anthocyanin forms $[3,4]$.

Literary sources provide information about the specifics of regulatory genes' expression under various environmental conditions [5,6] and depending on the genetic allelic combination [7]. Genetic polymorphism of the Anthocyanin1 gene has been studied in tomato and a marker to identify the Aft phenotype has been developed [7]. However, the genetic polymorphism of these genes in pepper and eggplant remains poorly explored. Thus, a relationship between the Capsicum Anthocyanin 2 activity and its promoter region's polymorphism has been established (LTR retrotransposon insertion defined as Ca-nLTR-A)[8].

In view of the above, our investigation aimed to identify DNA markers to the "anthocyanin accumulation in fruits" character for pepper and eggplant based on the comparative polymorphism of Anthocyanin 1 orthologs in tomato and the study of their allelic polymorphism in forms 
with different anthocyanin accumulation for the increased breeding efficiency of those species. The following investigative steps have been taken in this regard: a search for and a comparative analysis of pepper and eggplant genetic sequences similar in their nucleotide composition to the Anthocyanin 1 tomato gene; the study of the genetic polymorphism of sequences selected to compare genes in accessions with different intraspecies diversity based on the anthocyanin accumulation; the study of the relationship between identified polymorphisms and the phenotypic manifestation of the character "anthocyanin accumulation in fruits"; identification of DNA markers that allow to differentiate samples by anthocyanin accumulation.

\section{MATERIALS AND METHODS}

The objects of research were collection pepper accessions provided by the Institute of Genetics and Cytology, NAS of Belarus, the Belarusian State Agricultural Academy, and the Russian Federal Scientific Centre for Vegetable Growing, as well as eggplant accessions granted by the N.I. Vavilov All-Russian Institute of Plant Genetic Resources. Samples of the cultures under study were characterized by wide phenotypic polymorphism according to the "anthocyanin accumulation in fruits at the technical ripeness stage" character (hereinafter referred to as "TRS fruits”).

For sequencing, samples with a various anthocyanin coloration of $C$. annuum TRS fruits were used: Chernyj krasavets (dark purple), Fioletovyj krasavets (violet), Sirenevyj (lilac), Troika (green with light anthocyanin traces), Belosnezhka (light green), L-160-10 (whitish); S. melongena: Solaris (dark purple), Wegro prince (dark purple), Grushevidnyj (green), Crimson (pink), Zelenenkij (green), Pelikan (white), Snezhnyj (white). Along with $S$. melongena, the commercial variety Frant of the species $S$. aethiopicum characterized by light green fruits at the stage of technical ripeness was included in the analysis.

To study the relationship between identified polymorphisms based on the results of DNA typing and the phenotypic manifestation of an anthocyanin coloration in fruits, varieties and hybrids (30 eggplants and 30 peppers) were selected, as well as population pepper and eggplant material.

DNA was isolated from the leaves of pepper and eggplant accessions using the Genomic DNA Purification Kit (Thermo Scientific, Vilnius, Lihthuania) according to the protocol. The Ultrospec 3300 pro spectrophotometer (Amersham Biosciences Corp., Little Chalfont, UK) was used to determine DNA concentration. A DNA-probe for each variety was analyzed in triplicate.

The nucleotide sequences of selected Anthocyanin 1 orthologs in pepper and eggplant accessions with a contrasting coloration in fruits were identified by sequencing. Amplification fragments were obtained on the genomic DNA with designed gene-specific primers (Table 1, 
sequencing), separated in the $1.0 \%$ agarose gel, and then cut out and purified using the DNA Extraction Kit (Thermo Scientific) in line with producer's techniques. Sequencing reactions were performed using the Big Dye ${ }^{\circledR}$ Terminator v 3.1 Cycle Sequencing Kit (Applied Biosystems, Foster City, CA, USA) in line with producer's techniques. Sequencing reaction products were purified by ethanol precipitation and dissolved in $20 \mu \mathrm{L}$ of formamide, denatured by heating to $95{ }^{\circ} \mathrm{C}$ for $2 \mathrm{~min}$, and then capillary electrophoresis was performed using the $\mathrm{ABI}{ }^{\circledR}$ PRIS 310 Genetic Analyzer (Applied Biosystems, Foster City, CA, USA).

Table 1. List of primers used in the research.

\begin{tabular}{|c|c|c|c|c|}
\hline Crop & Gene & Primer & Sequencing & Designation \\
\hline \multirow[t]{5}{*}{ Pepper } & \multirow{2}{*}{$\begin{array}{l}\text { Myb113-like } \\
\text { (XM_016689227 - } \\
\text { GeneBank } \\
\text { Database } \\
\text { Accession Number) }\end{array}$} & $\begin{array}{l}\text { Myb113- } \\
\text { 1(1)caps }\end{array}$ & $\begin{array}{l}\text { F: ATGAACAGTACTCCGATTTTGGGA } \\
\text { R: GGGTTCAATCCCTGCCTCG }\end{array}$ & sequencing \\
\hline & & $\begin{array}{l}\text { Myb113- } \\
\text { 1(3)caps }\end{array}$ & $\begin{array}{l}\text { F: ATGCAGATGGTCACTTATGGCT } \\
\text { R: ATGAATTTTTGAACCCCTACAGCAA }\end{array}$ & $\begin{array}{l}\text { sequencing, CAPS } \\
\text { marker }(A c c \mathrm{I})\end{array}$ \\
\hline & \multirow{3}{*}{$\begin{array}{l}\text { Myb113-like } \\
\text { (NM_001324618- } \\
\text { GeneBank } \\
\text { Database } \\
\text { Accession Number) }\end{array}$} & $\begin{array}{l}\text { Myb113- } \\
\text { 2(2) caps }\end{array}$ & $\begin{array}{l}\text { F: TCCCTGCTTTGCATAAAAATCTCA } \\
\text { R: CTTGCCTGTTGCCTAGAAGC }\end{array}$ & sequencing \\
\hline & & $\begin{array}{l}\text { Myb113- } \\
\text { 2(4)caps }\end{array}$ & $\begin{array}{l}\text { F: GTCACTTATTGCTGGGAGATTGC } \\
\text { R: AGCAGAAAAGTCATCCCAACCA }\end{array}$ & sequencing \\
\hline & & $\begin{array}{l}\text { Myb113- } \\
\text { AciI }\end{array}$ & $\begin{array}{l}\text { F: } \\
\text { AAAGTACAATACTGCCCTCAAGATCAC } \\
\text { CG } \\
\text { R: GACGACGTTTCACTTGTGAGC } \\
\end{array}$ & dCAPS marker (AciI) \\
\hline \multirow[t]{2}{*}{ Eggplant } & \multirow{2}{*}{$\begin{array}{l}\text { Myb1 } \\
\text { (Sme2.5_05099.1- } \\
\text { Solgemomics } \\
\text { Database } \\
\text { Accession Number) }\end{array}$} & $\begin{array}{l}\text { Mybmel } \\
\text { (Ex 1-2) }\end{array}$ & $\begin{array}{l}\text { F: ACGTTCACCAAAGGGTTTGC } \\
\text { R: GTGCACCTGTTGCCTAAGAG }\end{array}$ & $\begin{array}{l}\text { sequencing, SCAR } \\
\text { marker, CAPS marker } \\
\text { (PstI) }\end{array}$ \\
\hline & & $\begin{array}{l}\text { Mybmel } \\
(\mathrm{Ex} 3)\end{array}$ & $\begin{array}{l}\text { F: ATGATGCCATGCATGCTGAA } \\
\text { R: ACACAGGAGA GATGTTGGGT }\end{array}$ & sequencing \\
\hline
\end{tabular}

The Sequencing Analysis Software v 5.2 (Applied Biosystems) program was used for alignment of the obtained sequences.

SCAR and CAPS markers were selected (Table 1) based on the identified polymorphism and used for DNA typing of compiled crop collections. The Primer-BLAST program on the website of the US National Center for Biotechnology Information was used for the primers' design [9].

The Biometra $\mathrm{T}$ Professional Basic Thermocycler (Biometra Biomedizinische Analytik GmbH, Göttingen, Germany) was used for PCR. The reaction $15 \mu \mathrm{L}$ PCR mixture contained 60-100 ng of genomic DNA, 2.5 $\mathrm{mM}$ of dNTP Mix (Thermo Scientific), 1.4 units of Tornado DNA polymerase in the incubation "F" buffer (Primetech, Minsk, Belarus) and $0.25 \mathrm{pmol} / \mu \mathrm{L}$ of oligonucleotide primers (Primetech, Minsk, Belarus). The PCR mode was as follows: $95{ }^{\circ} \mathrm{C}$ for $15 \mathrm{~min}$ and then 35 cycles consisting 
of incubations as follows: $99^{\circ} \mathrm{C}$ for $1 \mathrm{~s}, 55-60{ }^{\circ} \mathrm{C}$ for $30 \mathrm{sec}$ and $72{ }^{\circ} \mathrm{C}$ for 1 min. The reaction was completed at $72{ }^{\circ} \mathrm{C}$ for $7 \mathrm{~min}$.

PCR products were separated by the electrophoresis technique in the $2 \%$ agarose gel in the presence of ethidium bromide and documented using the Bio-Rad GelDoc2000 system (Hercules, Wilmington, DE, USA). The amplified fragments' size was identified using the 100 bp Plus DNA ladder (Thermo Scientific) as a molecular weight marker. PCR products were separated by electrophoresis in the polyacrylamide gel using the DNA sequencer (ABI PRISM ${ }^{\circledR} 310$ Genetic Analyzer (Applied Biosystems), and the SCAR marker MybMel. The amplicon size was determined using the Liz500 standard. Restriction with AccI, AciI, and PstI endonucleases was performed in line with producer's instructions (Thermo Scientific).

Based on the DNA typing results, optimal DNA markers were selected to identify the polymorphisms of accessions with no anthocyanin accumulation.

A search for homologous $M y b T F$ nucleotide sequences was performed using the BLAST program (Basic Local Alignment Search Tool) on the server of the US National Center for Biotechnology Information [10].

\section{RESULTS}

A search for orthologs to the tomato allele Ant1 (EF433416) in the GenBank Database (Supplementary Table S1) revealed in Capsicum annuum the following sequences closest by their nucleotide composition: Myb113-like transcription factors (TF) mRNA XM_016689227 and mRNA NM_001324618 (hereinafter referred to as Myb113-like 1 and Myb113-like 2) and in Solanum melongena: the Myb1 transcription factor mRNA KT259043 (or DNA KT27965) (hereinafter referred to as Myb1).

Based on the Solgenomics Database on the genomic DNA structure of Capsicum annuum (Pepper1.55ch10) and Solanum melongena (Sme2.5_05099.1), the primers completely overlapping the exons of the above genes were selected (Table 1). Using them, amplicons were obtained in the collection samples of pepper and eggplant with a contrasting anthocyanin coloration of TRS fruits by the PCR on genomic DNA and then sequenced. (Supplementary Figure S2-S4).

Comparative analysis of the obtained sequences of $C$. annuum accessions with a different level of anthocyanin accumulation in fruits allowed to identify the following polymorphism: 4SNPs and a single base deletion in the 3rd exon of the Myb113-like 1 allele in Belosnezhka and L160-10 varieties (Supplementary Figure S2) and 2 SNPs in the 4th exon of the Myb113-like 2 allele in Belosnezhka, Troika and L160-10 varieties (Supplementary Figure S3).

Comparison of the obtained sequences of the $M y b 1$ gene in $S$. melongena with the DNA sequence (Solgenomic Sme2.5_05099.1) revealed varied polymorphism: a 6 bp deletion at the end of exon 1 in Zelenenkij variety, or a 26 bp deletion between intron 1 and exon 2, 11 SNPs in exon regions and a $52 \mathrm{bp}$ insertion at the beginning of intron 2 in Snezhnyj 
and Pelican varieties. Also, the 3rd exon of Frant variety (S. aethiopicum) holds a 9-nucleotide insertion and 11 SNPs (Supplementary Figure S4(A,B)).
A

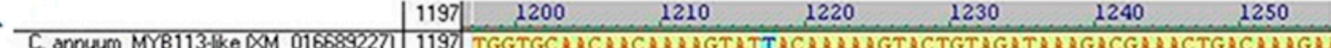

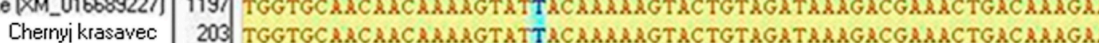

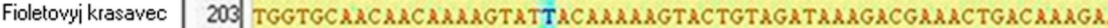

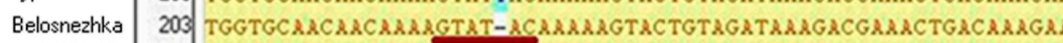
L-160-10 203 TGGTGCAACAACARAAGTAT-ACAARARGTACTGTAGATAARGACGAAACTGACARAGA.
restriction site $\mathrm{Accl} \quad$ exon 3
B C. annuum MYB113-tke [XM_016689227]
Chernyi krasavec
Fioletovyi krasavec

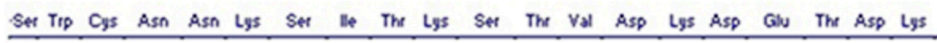 CGTGGTGCAR CAACAAARGT ATTACAAARA GTACTGTAGR TAAAGACGAR ACTGACAARG
stop codon
Belosnezhka
L.160-10

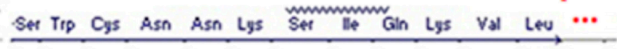
CGTGGTGCAR CARCARARGT ANACARARA TACTGTAGAT ARAGACGARA CTGACAARG

C

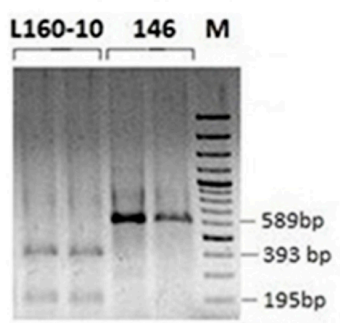

F

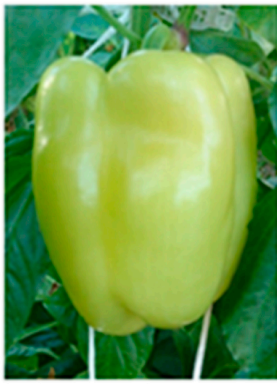

L-160-10

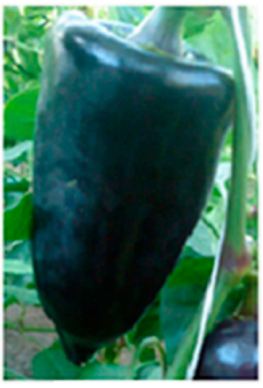

Chernyj Krasavec (146)

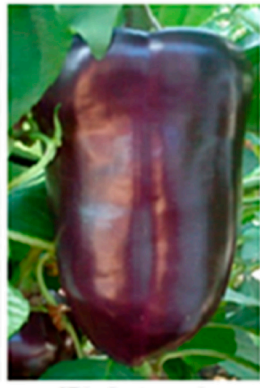

Fioletovyj

D

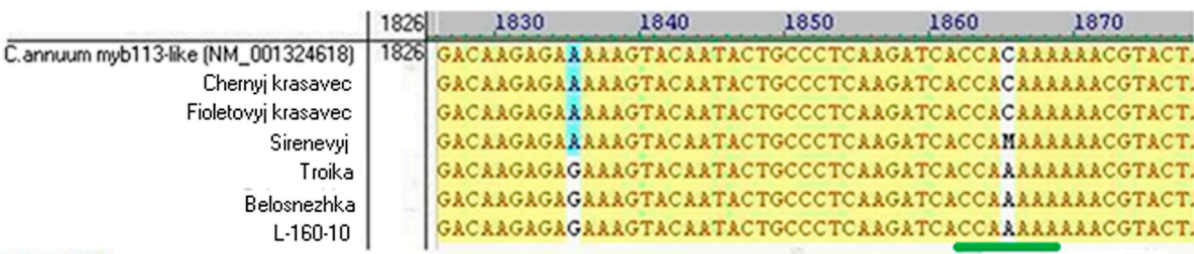

exon 4 dCAPS marker site

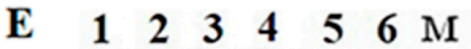

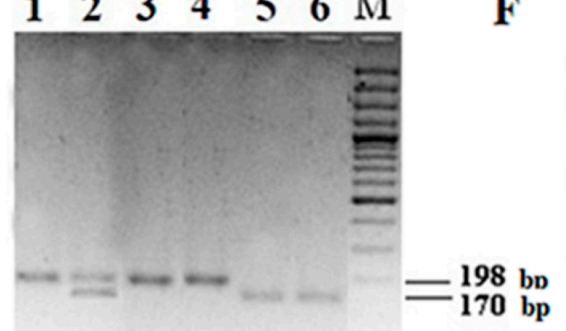

Lanes: 1 - Troika; 2 - Sirenevyj; 3 - Belosnezhka; 4 - L-160-10; 5 - Chernyj Krasavec; 6 - Fioletovyj Krasavec; M - DNA Ladder

dCAPS marker myb 113-AciI

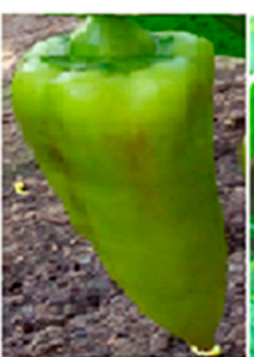

Troika

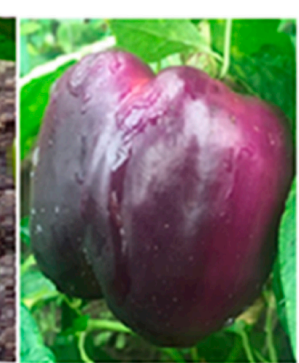

Sirenevyj

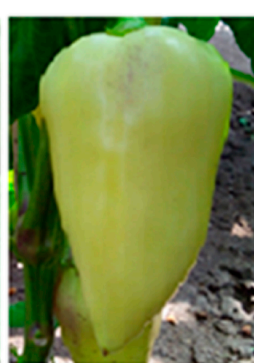

Belosnezhka

Figure 1. (A) a region of the 3rd exon of the Myb113-like 1 gene of Capsicum annuum, where a single nucleotide deletion (T) was detected; (B) reading frames in the $3^{\text {rd }}$ exon of wild-type and Myb113-like-delT alleles; (C) DNA identification of alleles using a CAPS Myb 113-AccI marker to collection pepper samples; (D) a region of the $4^{\text {th }}$ exon of the Myb113-like 2 gene of Capsicum annuum with detected SNPs (positions +1835 (A/G), +1865 (C/A)); (E) DNA identification of Myb113-like 2 alleles (C/A) using the dCAPS Myb 113-AciI marker to collection pepper samples; (F) phenotypic manifestation of identified polymorphisms. 
Based on the identified polymorphisms, pairs of primers were designed and markers were developed to study their relationship with the phenotypic manifestation of characters. A CAPS marker (Myb 113AccI) was developed to identify a deletion in the 3rd exon of Capsicum Myb113-like 1 (position +1217 Supplementary Figure S2, Figure 1A). The following primers were used: F: ATGCAGATGGTCACTTATGGCT and R: ATGAATTTTTGAACCCCTACAGCAA. After amplification with the above primers and subsequent AccI restriction, $589 \mathrm{bp}$ and $25 \mathrm{bp}$ fragments in the non-deletion allele (TT) and $393 \mathrm{bp}, 195 \mathrm{bp}$, and $25 \mathrm{bp}$ fragments with the thymine deletion allele (T-) were formed (Figure 1C).

A dCAPS marker (Myb113-AciI) was developed enabling the identification of SNP (C/A) in the 4th exon of Capsicum Myb113-like 2 (+1865 Supplementary Figure S3, Figure 1D). The following pair of primers was used: F: AAAGTACAATACTGCCCTCAAGATCACCG and R: GACGACGTTTCACTTGTGAGC.

When using that marker, two fragments of $170 \mathrm{bp}$ and $28 \mathrm{bp}$ were formed in the allele with the cytosine (C) position +1865 and in the allele with the adenine (A) position +1865 the amplicon remained unchanged (198 bp) (Figure 1E).

For a more detailed study of the SNP C/A (+1865) effect on the phenotypic character manifestation, the fissile generation of the Sirenevyj sample heterozygous by that polymorphism was typed and 15 plants with alleles AA, AC, and CC (45 in total) were planted (Figure 2).

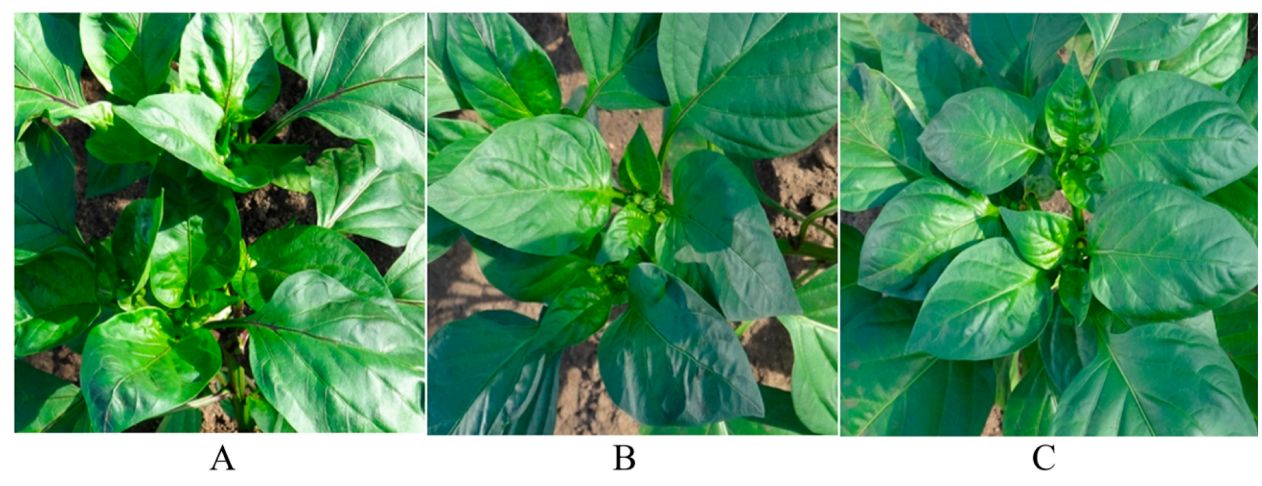

Figure 2. Phenotypic manifestation of Myb113-like2- (C/A) alleles of $F_{2}$ Sirenevyj pepper samples using the Myb113-AciI marker ((A) $\left.\mathrm{P}_{\mathrm{S}}-M y b 113-l i k e(2)-C C\right)$; (B) $\left.\mathrm{P}_{\mathrm{s}}-M y b 113-l i k e(2)-C A\right)$; (C) $\left.\mathrm{P}_{\mathrm{s}}-M y b 113-l i k e(2)-\mathrm{AA}\right)$.

SCAR and CAPS markers were developed to detect polymorphisms in the $S$. melongena Myb1 gene-a 6 bp deletion at the end of exon 1 and a 26 bp deletion between intron 1 and exon 2 (Supplementary Figure S4(A,B); Figure 3A). The Mybmel SCAR marker allows detecting both deletions. A $26 \mathrm{bp}$ deletion allele is easily distinguishable on the agarose gel after the amplification and electrophoresis of products (Figure 3D). For the clear separation of products with minimal differences in size (a 6 bp deletion allele), the Mybmel forward primer with a fluorescent label and a subsequent product analysis on the genetic analyzer was used (Figure 3E). The method also made it possible to clearly identify 
heterozygous forms for that gene. In cases where a genetic analyser could not be used, PstI restrictase (CAPS marker Mybmel-PstI) was selected for the 6 bp deletion identification. After amplification and subsequent restriction in the wild allele type, as well as in the $26 \mathrm{bp}$ deletion allele, the amplicon is not cut (458 and 432 bp remain, respectively), and 28 and $224 \mathrm{bp}$ fragments are formed in the $6 \mathrm{bp}$ deletion allele variant (Figure 3D).

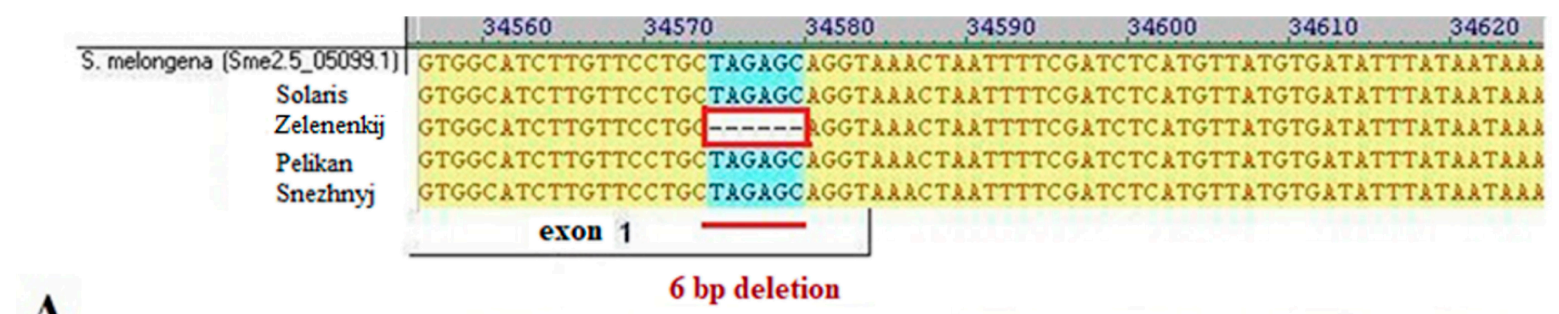

A

\begin{tabular}{l|llllllll} 
& 34630 & 34640 & 34650 & 34660 & 34670 & 34680 & & 34690 \\
\hline
\end{tabular}

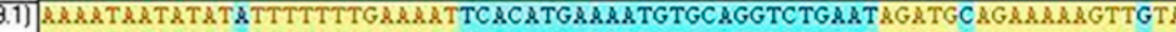

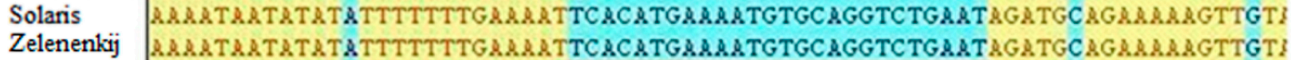

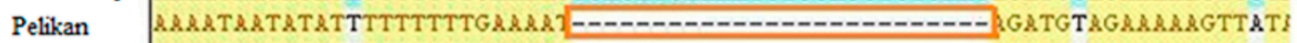

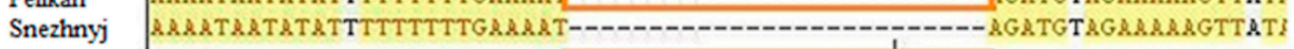

26 bp deletion

exon 2

B

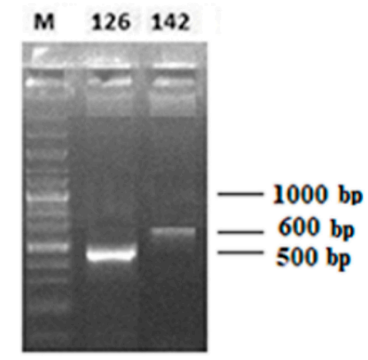

D

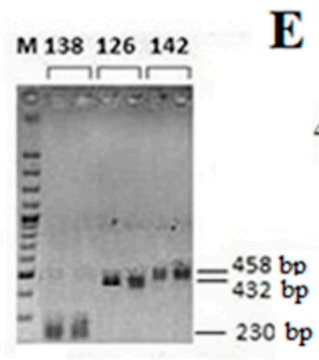

CAPS marker Mybmel-PstI

C

Pelikan Myb1-del26

Exon I

\begin{tabular}{|l|l|l|}
\hline Exon I & Exon II & Exon III \\
\hline
\end{tabular}

Solaris Myb1 (WT)

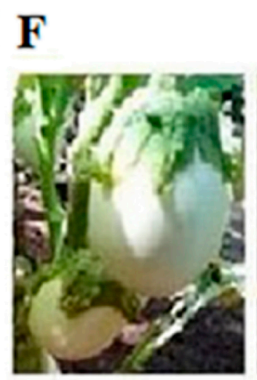

126

Pelikan

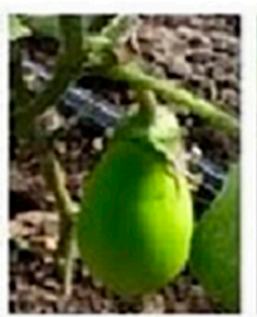

138

Zelenenkij

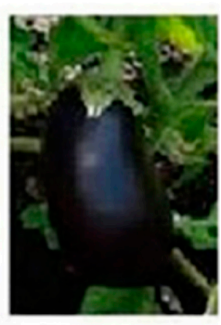

142

Solaris

Figure 3. (A) a region of the Myb1 gene of Solanum melongena with detected deletions in Myb1-del6 and Myb1-del26 alleles ; (B) electrophoresis of amplification products using mybmel-e1F/mybmel-e3R primers on eggplant cDNA as a matrix; (C) a structure of mature mRNA in eggplant with normal Myb1 (wild type) and mutant Myb1-del26 alleles; (D,E) DNA identification of Myb1-del6 (228 bp and 224 bp fragments), Myb1-del26 (432 bp fragment) and Myb1 ${ }^{w t}$ (458 bp product) using the CAPS Mybmel-PstI marker (D) or the SCAR MybMel marker (E) to collection eggplant samples; (F) phenotypic manifestation of identified polymorphisms.

For DNA typing, a 9 bp insertion in the 3rd exon of the Myb1 allele (variety Frant S. aethiopicum Supplementary Figure S4), CAPS marker 
Myb1-Ins9bp-Tru1l was developed using primers $\mathrm{F}$ : ATGATGCCATGCATGCTGAA and R: TTCTCCTTCAACAGCGTCGT and Tru1l restrictase. Amplified products with this marker in S.melongena accessions-412 bp and in Frant S.ephyopicum—421 bp. After restriction, products in S. melongena accessions are cut into $238 \mathrm{bp}$ and $174 \mathrm{bp}$, in Frant-into 238 bp, 152 bp and 31 bp.

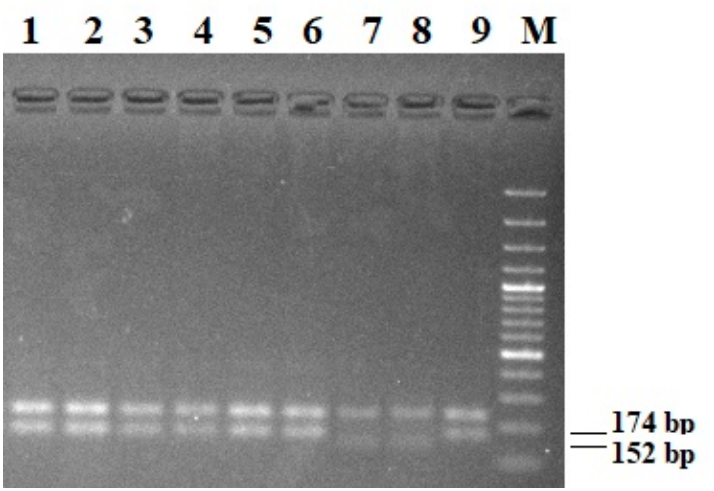

Figure 4. DNA identification of the Myb1-Ins9 allele using the Myb-Ins9bp_Tru1l CAPS marker: (M) a molecular weight marker; $(\mathbf{1 , 2})$ Grushevidnyj var.; $(3,4)$ Pelikan var., (5,6) Zelenenkij var., $(7,8)$ Frant var., (9) Balu var.

Tables 2 and 3 show genotyping results and the phenotypic manifestation of an anthocyanin coloration (an intensity degree) in STR fruits, as well as on stems and leaves.

Table 2. Genotyping results of collection Capsicum spp. samples using dCAPS and CAPS markers.

\begin{tabular}{|l|l|l|l|l|}
\hline Variety & $\begin{array}{l}\text { Fruit coloration at the } \\
\text { technical ripeness stage }\end{array}$ & $\begin{array}{l}\text { Anthocyanin coloration } \\
\text { intensity on the stem } \\
\text { and leaves }\end{array}$ & $\begin{array}{l}\text { Marker CAPS } \\
\text { Myb113-AccI }\end{array}$ & $\begin{array}{l}\text { Marker } \\
\text { dCAPS } \\
\text { Myb113-AciI }\end{array}$ \\
\hline Mulat & dark green & missing & TT* & AA \\
\hline $\begin{array}{l}\text { Oranzhevoe } \\
\text { naslazhdenie }\end{array}$ & green & weak in stem joints & T- & AA \\
\hline Igrok & white, fruit tip is lilac & weak in stem joints & T- & CC $^{* *}$ \\
\hline L-160-10 & white & weak in stem joints & T- & AA \\
\hline L-45-11 & dark green & $\begin{array}{l}\text { intensely coloured } \\
\text { stem joints }\end{array}$ & TT & CC \\
\hline Zheltoplodnyj & white & weak in stem joints & T- & AA \\
\hline Zlatozar & green & missing & AA \\
\hline Sirenevyj & lilac & $\begin{array}{l}\text { high in stem joints, on } \\
\text { leaf petioles and in } \\
\text { veins }\end{array}$ & TT & AC \\
\hline $\begin{array}{l}\text { Shokoladnaya } \\
\text { krasavitca }\end{array}$ & dark green & $\begin{array}{l}\text { average in stem joints, } \\
\text { on leaf petioles }\end{array}$ & T- & AA \\
\hline $\begin{array}{l}\text { Fioletovyj } \\
\text { krasavec }\end{array}$ & violet & $\begin{array}{l}\text { high in stem joints, on } \\
\text { leaf petioles and in } \\
\text { veins }\end{array}$ & TT & CC \\
\hline
\end{tabular}


Table 2. Cont.

\begin{tabular}{|c|c|c|c|c|}
\hline Variety & $\begin{array}{l}\text { Fruit coloration at the } \\
\text { technical ripeness stage }\end{array}$ & $\begin{array}{l}\text { Anthocyanin } \\
\text { coloration intensity on } \\
\text { the stem and leaves }\end{array}$ & $\begin{array}{l}\text { Marker CAPS } \\
\text { Myb113-AccI }\end{array}$ & $\begin{array}{l}\text { Marker dCAPS } \\
\text { Myb113-AciI }\end{array}$ \\
\hline L24 & white & weak in stem joints & $\mathrm{T}-$ & AA \\
\hline $\begin{array}{l}\text { Oranzhevoe } \\
\text { chudo }\end{array}$ & dark green & missing & TT & AA \\
\hline Zong Kao & dark green & light in stem joints & TT & AA \\
\hline Ami & white & $\begin{array}{l}\text { weak in stem joints, on } \\
\text { leaf petioles }\end{array}$ & $\mathrm{T}-$ & AA \\
\hline Volat & light green & weak in stem joints & $\mathrm{T}-$ & AA \\
\hline Boneta & $\begin{array}{l}\text { light green fruit tip is } \\
\text { lilac, }\end{array}$ & weak in stem joints & TT & AA \\
\hline Oda & violet & $\begin{array}{l}\text { high in stem joints, on } \\
\text { leaf petioles and in } \\
\text { veins }\end{array}$ & TT & $\mathrm{CC}$ \\
\hline Troika & green & $\begin{array}{l}\text { average in stem joints, } \\
\text { on leaf petioles }\end{array}$ & TT & AA \\
\hline Otello & violet & $\begin{array}{l}\text { high in stem joints, on } \\
\text { leaf petioles and in } \\
\text { veins }\end{array}$ & TT & AA \\
\hline Belosnezhka & white & $\begin{array}{l}\text { weak in stem joints, on } \\
\text { leaf petioles }\end{array}$ & $\mathrm{T}-$ & AA \\
\hline Chernyj Krasavec & dark purple & $\begin{array}{l}\text { high in stem joints, on } \\
\text { leaf petioles and in } \\
\text { veins }\end{array}$ & TT & $\mathrm{CC}$ \\
\hline $\begin{array}{l}\text { Chyrvony } \\
\text { magnat }\end{array}$ & dark green & $\begin{array}{l}\text { high in stem joints, on } \\
\text { leaf petioles }\end{array}$ & $\mathrm{T}-$ & $\mathrm{CC}$ \\
\hline Solnyshko & green & $\begin{array}{l}\text { weak in stem joints, on } \\
\text { leaf petioles }\end{array}$ & $\mathrm{T}-$ & AA \\
\hline Karamel & green, fruit tip is lilac & $\begin{array}{l}\text { high in stem joints, on } \\
\text { leaf petioles }\end{array}$ & TT & $\mathrm{CC}$ \\
\hline Yazyk drakona & $\begin{array}{l}\text { dark green, fruit tip is } \\
\text { violet }\end{array}$ & high in stem joints & TT & $\mathrm{CC}$ \\
\hline Yubilejnyj & green & weak in stem joints & $\mathrm{T}-$ & AA \\
\hline Ognennaya deva & green & high in stem joints & $\mathrm{T}-$ & $\mathrm{CC}$ \\
\hline $\begin{array}{l}\text { Sozvezdie, } C \text {. } \\
\text { frutescens }\end{array}$ & violet & $\begin{array}{l}\text { high in stem joints, on } \\
\text { leaf petioles and in } \\
\text { veins }\end{array}$ & TT & $\mathrm{CC}$ \\
\hline $\begin{array}{l}\text { Ryabinushka, } C . \\
\text { frutescens }\end{array}$ & violet & $\begin{array}{l}\text { high in stem joints, on } \\
\text { leaf petioles and in } \\
\text { veins }\end{array}$ & TT & $\mathrm{CC}$ \\
\hline $\begin{array}{l}\text { Malenkij princ, } C \text {. } \\
\text { baccatum }\end{array}$ & light green & weak in stem joints & $\mathrm{T}-$ & AA \\
\hline
\end{tabular}

* mRNA sequence XM_016689227 polymorphism (TT), ${ }^{* *}$ mRNA sequence NM_001324618 polymorphism (CC). 
Table 3. Genotyping results of collection eggplant samples using MybMel SCAR and Myb-Ins9bp-Tru1l CAPS markers.

\begin{tabular}{|c|c|c|c|c|}
\hline Variety & $\begin{array}{l}\text { Fruit coloration at } \\
\text { the technical } \\
\text { ripeness stage }\end{array}$ & $\begin{array}{l}\text { Anthocyanin } \\
\text { coloration intensity on } \\
\text { the stem and leaves }\end{array}$ & $\begin{array}{l}\text { PCR product } \\
\text { size, bp }\end{array}$ & Allele \\
\hline Karlson & deep purple & average & 458 & Myb1 \\
\hline Drakosha & black & weak & 458 & Myb1 \\
\hline $\begin{array}{l}\text { Donecky } \\
\text { urozhaynyj }\end{array}$ & green & missing & 452 & myb1-del6 \\
\hline Chernomorec & black & average & 458 & Myb1 \\
\hline Pelikan & white & missing & 432 & Myb1-del26 \\
\hline$F_{1}$ Agat & violet & weak & 458 & Myb1 \\
\hline Chernyj Krasavec & black & average & 458 & Myb1 \\
\hline Grushevidnyj & green & high & 458 & Myb1 \\
\hline $\begin{array}{l}\text { Gribnoe } \\
\text { udovolstvie }\end{array}$ & black purple & average & 458 & Myb1 \\
\hline $\begin{array}{l}\text { Sadohara naga } \\
\text { nasu }\end{array}$ & dark pink* & missing & 458,432 & $\begin{array}{l}\text { Myb1/ } \\
\text { Myb1-del26 }\end{array}$ \\
\hline Shina omaru nasu & dark violet & average & 458 & Myb1 \\
\hline $\begin{array}{l}\text { F }_{1} \text { Korol severa } \times \\
\text { Shina omaru nasu }\end{array}$ & ink & average & 458 & Myb1 \\
\hline Nezhnejshyj & white & missing & 432 & Myb1-del26 \\
\hline Pekinskij chornyj & red violet & average & 458 & Myb1 \\
\hline Wegro prince & violet & weak & 458 & Myb1 \\
\hline Crimson & violet & weak & 458 & Myb1 \\
\hline Belyj iz Keredzha & pink & weak & 458,432 & $\begin{array}{l}\text { Myb1/Myb1- } \\
\text { del26 }\end{array}$ \\
\hline Fioletovyj dlinnyj & violet & weak & 458 & Myb1 \\
\hline Zelenenkij & green & missing & 452 & Myb1-del6 \\
\hline Snezhnyj & white & missing & 432 & Myb1-del26 \\
\hline Galaktika & dark violet & average & 458 & Myb1 \\
\hline Solaris & violet & weak & 458 & Myb1 \\
\hline Noire hative & green purple & missing & 458 & Myb1 \\
\hline Purple round & light purple & weak & 458 & Myb1 \\
\hline Belomyasyj 155 & violet & weak & 458 & Myb1 \\
\hline Buckbee's white & violet & missing & 458 & Myb1 \\
\hline$F_{1}$ Sindbad ametist & light purple & weak & 458 & Myb1 \\
\hline $\begin{array}{l}\mathrm{F}_{1} \text { Sindbad } \\
\text { pinkstrip }\end{array}$ & deep lilac ** & missing & 458 & Myb1 \\
\hline Mramornyj & light purple $* *$ & weak & 458 & Myb1 \\
\hline Balu & raspberry violet & weak & 458 & Myb1 \\
\hline $\begin{array}{l}\text { Frant, } S \text {. } \\
\text { aethiopicum }\end{array}$ & light green & $\begin{array}{l}\text { missing or weak, white } \\
\text { flower corolla }\end{array}$ & $\begin{array}{l}458 \\
238,152^{* * *}\end{array}$ & Myb1-ins9 \\
\hline
\end{tabular}

* green white in the upper part of fruit due to the $g s$ allele; ** coloration with a marble white pattern due to the $g s$ allele, ${ }^{* * *}$ myb-Ins9bp-Tru1l CAPS. 


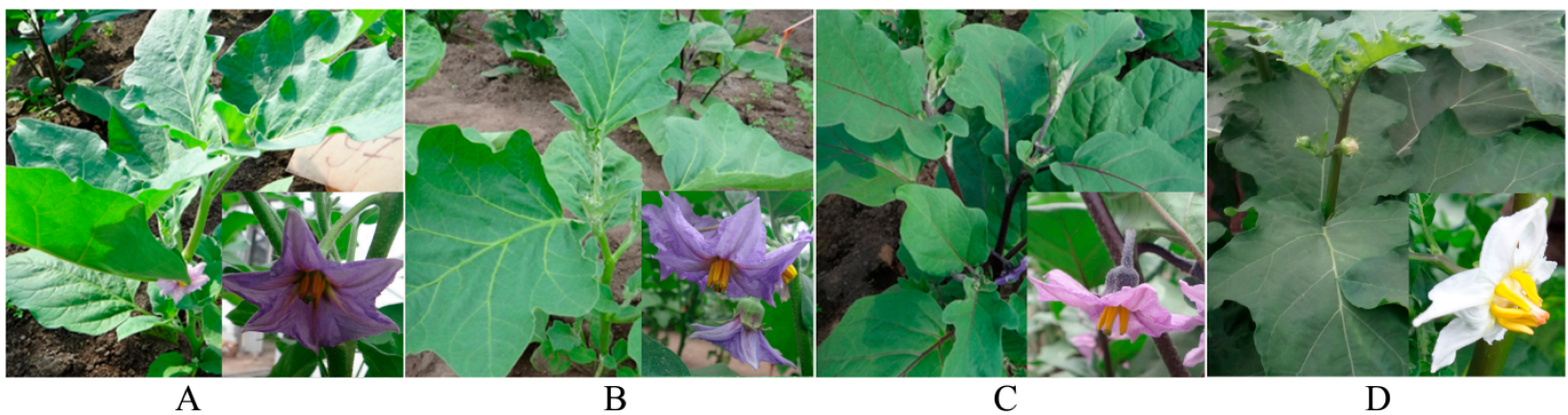

Figure 5. Manifestation of anthocyanin coloration intensity on the stem, leaves and flower corolla in varieties with identified polymorphisms: (A) Snezhnyj (Myb1-del26), (B) Zelenenkij (Myb1-del6), (C) Grushevidnyj (Myb1), (D) Frant (Myb1-ins9).

\section{DISCUSSION}

\section{Selection of Orthologous Sequences, the Identified Polymorphisms' Value}

Due to the fact that the nomenclature of Myb-orthologous genes in different Solanaceous species is not consistent [2] and is also based on Vavilov's law of homologous series in the hereditary variation [11], the selection of sequences for the study was carried out according to the results of a comparative analysis of Capsicum annuum and Solanum melongena sequences presented in the GenBank database with the Anthocyanin 1 (Ant1, EF433416) gene sequence of tomato.

Based on Blast analysis results, the query cover of selected sequences mRNA of Myb113-like TFs C.annuum with Ant1 was 56-65\%, and mRNA of Myb1 TF S. melongena with Ant1 was 91-92\%. The percent identity in the query cover was $82-86 \%$. (Supplementary Table S1). A comparative analysis of the above sequences (hereinafter referred to as "normal Myb TF alleles") with the sequences obtained in C. annuum accessions with the minimal or no accumulation of anthocyanin in fruits revealed the following polymorphism: 4SNPs and one base deletion (Figure 1A) in the 3rd exon of the Myb113-like 1 allele in Belosnezhka varieties; L160-10 and 2 SNPs in the 4th exon of the Myb113-like 2 allele in Belosnezhka, Troika, and L160-10 varieties (Figure 1D).

A single nucleotide deletion in the 3rd exon of the Myb113-like 1 allele (position +1218 ) leads to a shift in the reading frame with the formation of a terminating codon in $14 \mathrm{bp}$ after nucleotide dropout and truncated protein synthesis (Figure 1B). To this mutation, we have developed and successfully tested the CAPS marker of Myb113-AccI. SNP (G/A) (position +1042 ) leads to the replacement of serine with asparagine in the protein sequence. Three SNPs (positions $+1277,+1288,+1435$ ) in the 3rd exon of the Myb113-like 1 allele in these varieties no longer affect the protein structure, since they are located below the deletion (thymine dropout), which leads to the appearance of a premature terminating codon. Single nucleotide polymorphisms in the 4th exon of the Myb113-like 2 gene lead to amino acid substitutions in the protein sequence: lysine for arginine 
(position +1835 ) and threonine for lysine (position +1865$)$. Based on the identified SNP at position +1865 (C/A) in the 4th exon of the Myb 113-like 2 allele, the dCAPS marker of Myb 113-AciI has been selected and successfully tested.

Comparison of the obtained sequences of the Myb1 gene in $S$. melongena in varieties with no anthocyanin accumulation in fruits revealed the following polymorphism: a $6 \mathrm{bp}$ deletion at the end of exon 1 of the Myb1 gene (Figure 3A, Supplementary Figure S4), which leads to the dropout of two amino acids in the protein of the Zelyenenkij variety with a green coloration of fruits. For eggplant varieties Pelican and Snezhnyj with a white fruit coloration, a 26 bp deletion between intron 1 and exon 2 (Figure 3A, Supplementary Figure S4), 11 SNPs in coding regions and also a $52 \mathrm{bp}$ insertion at the beginning of intron 2 were detected. We made an assumption that in eggplant accessions with a 26 bp deletion in the studied Myb1 gene, mRHK maturation is impaired and a functional protein is not formed. To test the afore-mentioned hypothesis, the identified deletion effect in the Myb1-del26 allele on mRNA splicing was studied. For that purpose, total RNA was isolated from the leaves of Pelican (Myb1-del26) and Solaris (Myb1) varieties. Preparations were treated with DNAase and then cDNA was synthesized, using the designed primers mybmel-e1F (TGTACGTCTGTGCGAGTGAG) and mybmel-3R (TTCTCCTTCAACAGCGTCGT) to the 1st and 3rd exons of the Myb1 gene. After PCR on the cDNA matrix, amplicons were obtained in Solaris (588 bp) and Pelican (459 bp) varieties, and their electrophoresis (Figure 3B) and sequences were performed. A comparative analysis showed that, unlike the Solaris variety, exon 2 is completely absent in the mature mRNA of the Pelican variety homozygous by the Myb1-del26 allele (Figure 3C), and consequently, a functional protein is not formed. Thus, it was shown that a $26 \mathrm{bp}$ deletion (possibly jointly with a $52 \mathrm{bp}$ insertion in the intron region, Supplementary Figure S4A) in the Myb1 gene causes the dropout of exon 2 of mature mRNA during splicing and leads to the impaired synthesis of a native functional protein.

In the S. aethiopicum Frant variety, in exon 3 of the Myb1 gene, the insertion of 9 nucleotides and 11 SNPs, which lead to 8 amino acid substitutions and the appearance of three additional amino acids in the protein structure, was detected (Supplementary Figure S5). For this variety, a white flower corolla coloration is characteristic along with the absence of anthocyanins in fruits (Figure 5). Perhaps, the identified polymorphisms also determine this character. To study that assumption, $\mathrm{F}_{0}$ hybrids were developed for the above variety and S. melongena accessions with the different polymorphism of the Myb1 gene. Further research on $\mathrm{F}_{1-2}$ generation hybrids is planned. 


\section{Analysis of DNA Typing of Collection Samples and Phenotypic Manifestations of Anthocyanin Accumulation}

Collection samples of pepper and eggplant were typed using the designed markers to identified polymorphisms. The obtained results were compared with the phenotypic manifestation of an anthocyanin coloration in STR fruits. Despite the strong dependence of anthocyanin accumulation on the level of solar radiation, fairly clear dependence was observed between revealed polymorphisms and the manifestation of studied characters.

Analysis of the DNA typing results of collection Capsicum spp. samples showed that the strongest manifestation of an anthocyanin coloration in fruits was observed in combination of the Myb113-like 1-TT allele with no deletion (thymine dropout position +1217) with the Myb113-like 2-CC allele (cytosine position +1865 ) in the genome. In that case, a high intensity of an anthocyanin coloration was observed in stem joints, on leaf petioles and in veins. Such polymorphisms were characteristic of normal Myb113-like factor alleles.

For most varieties with no anthocyanin coloration in STR fruits, Myb113-like 1-delT (thymine dropout at position +1217) and Myb113-like $2-A A$ (adenine at position +1865 ) alleles are characteristic.

In case of allele combination with TT and AA or T- and CC polymorphisms (Myb113-like 1 and Myb113-like 2 respectively), an anthocyanin coloration was weak or partially manifested under the conditions of direct strong solar radiation. When evaluating fissile generation $\mathrm{F}_{2}$ of Sirenevyj variety (Myb113-like 1-TT and Myb113-like 2$C A$ alleles), differences were revealed according to anthocyanin accumulation in stem joints and leaf veins and the manifestation degree in STR fruits. It was confirmed that the most active anthocyanin synthesis occurs in the Myb113-like 1-TT and Myb113-like 2-CC allele combination and the lowest one in case of Myb113-like 1-TT and Myb113-like 2-AA alleles. In the allele combination of Myb113-like 1-TT and Myb113-like 2$A C$, moderate or weak anthocyanin accumulation in leaves and stems was observed (Figure 2). At that, an anthocyanin synthesis in the STR fruits of that population was observed in all three combinations with a maximum degree of its manifestation in genotypes with Myb113-like1-TT and Myb113-like 2-CC alleles

Our results suggest a weakening anthocyanin biosynthesis process in the presence of T- (Myb113-like1) and AA (Myb113-like2) polymorphisms in the samples. We believe that these alleles have an additional effect along with other and possibly more important genes, since the anthocyanin coloration intensity was different with the similar alleles of Myb-TFs (L45-11, Fioletovyj krasavec, Karamel -Table 2).

In $S$. melongena varieties, there was a lack of anthocyanin in the fruits of forms with detected deletions in the coding region of the Myb1 gene. Thus, the STR fruits of samples with a $6 \mathrm{bp}$ deletion were green and with a 26 bp deletion were of a white coloration. Forms with a heterozygous 
combination of normal and deleted alleles had a pink coloration of STR fruits. Phenotypic observations showed a lack of synthesis of anthocyanins not only in STR fruits, but also on stems and leaves of the forms with identified polymorphisms (Figure 5).

In our study, the presence of identified polymorphisms in the homozygous form of eggplant always corresponded to the described phenotypic manifestations: Myb1-del6-a green coloration of fruits and Myb1-del26-a white coloration of fruits. We assume that the functions of Ant1 (tomato) and Myb1 (eggplant) are closer, since they belong to the same genus and the Myb1 role in the accumulation of anthocyanins in eggplant fruits is as important as of Ant1 in tomato. Based on the analysis results, Grushevidnyj variety (with the normal $M y b-1$ allele) was distinguished in the collection under study characterized by an intense violet coloration of the vegetative part of its plants characteristic of the normal $M y b-1$ allele identified in it. At the same time, the coloration of STR fruits (fruits at the technical ripeness stage) was green, although a purple coloration was expected. Perhaps, such phenotypic manifestation is caused by the action of other genes that determine anthocyanin biosynthesis.

\section{CONCLUSIONS}

Based on the analysis of sequenced Anthocyanin 1 tomato orthologs in pepper and eggplant forms with wide intraspecies diversity by the anthocyanin accumulation in fruits, the allelic polymorphism of Myb113like factors, mRNA XM_016689227 (Myb113-like1) and mRNA NM_001324618 (Myb113-like2) of pepper and Myb1 mRNA KF72747 of eggplant, was identified for the first time.

In Capsicum spp. samples, 4SNP and a single base deletion in the 3rd exon of Myb113-like 1 and 2 SNP in the 4th exon of Myb113-like2 were detected in forms with the impaired anthocyanin synthesis.

In Solanum melongena samples, a $6 \mathrm{bp}$ deletion at the end of exon 1 of the $M y b-1$ gene was detected in forms with a green coloration of fruits; a 26 bp deletion between intron 1 and exon 2, 11 SNP in exon regions and a $52 \mathrm{bp}$ insertion at the beginning of intron 2 were detected in forms with a white coloration of fruits. Also, 9-nucleotide insertion and 11 SNPs in the 3th exon of the $M y b-1$ gene were identified in the Solanum aethiopicum form with no anthocyanin accumulation in fruits.

Optimal SCAR and CAPS markers were developed to identify a number of genetic polymorphisms of the studied Myb-like TF genes that cause the impaired synthesis of anthocyanins in pepper and eggplant fruits. CAPS Myb 113-AccI and dCAPS Myb 113-AciI markers allow to identify C.annuum accessions without the anthocyanin coloration of fruits. SCAR MybMel and CAPS Mybmel-PstI markers allow to identify $S$. melongena accessions with white and green fruit colorations. C.annuum and S.melongena samples with a different combination of allelic polymorphism were selected as models for the further study of the 
genetic regulation of anthocyanin accumulation in various parts of plants and for the increased breeding efficiency.

\section{SUPPLEMENTARY MATERIALS}

The following supplementary materials are available online at https://doi.org/10.20900/cbgg20200011:

Supplementary Table S1. Blast analysis results in the search for ANT1 (EF433416) tomato sequence orthologs in pepper and eggplant;

Supplementary Figure S1. Nucleotide sequence polymorphism of the 3rd exon of the Myb113-like 1 pepper gene in varieties with a contrasting anthocyanin coloration of fruits at the stage of technical ripeness;

Supplementary Figure S2. Nucleotide sequence polymorphism of the 4th exon of the Myb113-like 2 pepper gene in varieties with a contrasting anthocyanin coloration of fruits at the stage of technical ripeness;

Supplementary Figure S3. (A) Nucleotide sequence polymorphism of the exon 1-2 of the Myb1 gene in S. melongena and S.aethiopicum varieties with a contrasting anthocyanin coloration of fruits at the stage of technical ripeness. (B) Nucleotide sequence polymorphism of the 3rd exon of the Myb1 gene in S. melongena and S.aethiopicum varieties with a contrasting anthocyanin coloration of fruits at the stage of technical ripeness;

Supplementary Figure S4. Alignment of the amino acid sequences of the full-size transcription factor Myb1 (KT727965) with the corresponding sequence of $S$. aethiopicum in variety Frant.

\section{DATA AVAILABILITY}

All data generated from the study are available in the manuscript or supplementary files.

\section{AUTHOR CONTRIBUTIONS}

OB and AK developed the experiment; KY performed DNA sequencing; $\mathrm{OB}, \mathrm{TN}, \mathrm{NN}$, and KY carried out field and DNA-typing experiments; OB, $\mathrm{TN}$, and NN, and KY designed tables and figures; OB and AK analyzed the data obtained and wrote the paper.

\section{CONFLICTS OF INTEREST}

The authors declare that they have no conflict of interest.

\section{FUNDING}

The research was supported by the State Scientific Research Program "Biotechnologies 02" of the Republic of Belarus in the framework of projects 2.01 (N SR 20160201) and 2.25 (N SR 20190367). 


\section{ACKNOWLEDGMENTS}

The authors would like to thank colleagues from the Russian Federal Scientific Centre for Vegetable Growing for providing $C$. annuum accessions; colleagues from the N.I. Vavilov All-Russian Institute of Plant Genetic Resources for providing S. melongena accessions; M. Pyzhova, the Institute of Genetics and Cytology, for assisting in editing the paper. We also express gratitude to the Organizing Committee of the 17th Capsicum and Eggplant Eucarpia Meeting and the CBGG Editorial Office for providing us with an opportunity to publish the Article.

\section{REFERENCES}

1. Adzhieva VF, Babak OG, Shoeva OY, Kilchevsky AV, Khlestkina EK. Molecular Genetic Mechanisms of the Development of Fruit and Seed Coloration in Plants. Russ J Genet Appl Res. 2016;6(5):537-52. doi: 10.1134/S2079059716050026

2. Liu Y, Tikunov Y, Schouten RE, Marcelis L, Visser R, Bovy A. Anthocyanin biosynthesis and degradation mechanisms in Solanaceous Vegetables: a review. Front Chem. 2018;6(52):1-17. doi: 10.3389/fchem.2018.00052

3. GenBank. Available from: https://www.ncbi.nlm.nih.gov/genbank/. Accessed 2019 Nov 29.

4. Solgenomics. Available from: https://solgenomics.net/. Accessed 2019 Nov 29.

5. Stommel JR, Dumm JM. Coordinated regulation of biosynthetic and regulatory genes coincides with anthocyanin accumulation in developing eggplant fruit. J Am Soc Hortic Sci. 2015;140(2):129-35. doi: 10.21273/JASHS.140.2.129

6. Lightbourn GJ, Stommel JR, Griesbach RJ. Epistatic interactions influencing anthocyanin gene expression in Capsicum annuum. J Am Soc Hortic Sci. 2007;132(6):824-9. doi: 10.21273/JASHS.132.6.824

7. Sapir M, Oren-Shamir M, Ovadia R, Reuveni M, Evenor D, Tadmor Y, et al. Molecular Aspects of Anthocyanin fruit Tomato in Relation to high pigment1. J Hered. 2008;99(3):292-303. doi: 10.1093/jhered/esm128

8. Jung S, Venkatesh J, Kang M-Y, Kwon J-K, Kang B-C. A non-LTR retrotransposon activates anthocyanin biosynthesis by regulating a MYB transcription factor in Capsicum annuum. Plant Sci. 2019;287:110181. doi: 10.1016/j.plantsci.2019.110181

9. Ye J, Coulouris G, Zaretskaya I, Cutcutache I, Rozen S, Madden T. PrimerBLAST: A tool to design target-specific primers for polymerase chain reaction. BMC Bioinformatics. 2012;13:134. doi: 10.1186\%2F1471-2105-13-134

10. Basic Local Alignment Search Tool on the server of the US National Center for Biotechnology Information. Available from: http://www.ncbi.nlm.nih.gov/BLAST. Accessed 2019 Nov 29. 
11. Kupzow AJ. Vavilov's Law of Homologous Series at the fiftieth anniversary of its formulation. Econ Bot. 1975;29(4):372-9.

How to cite this article:

Babak O, Nikitinskaya T, Nekrashevich N, Yatsevich K, Kilchevsky A. Identification of DNA Markers of Anthocyanin Biosynthesis Disorders Based on the Polymorphism of Anthocyanin 1 Tomato Ortholog Genes in Pepper and Eggplant. Crop Breed Genet Genom. 2020;2(3):e200011. https://doi.org/10.20900/cbgg20200011 